\title{
Assessment of the level of the sense of coherence and its relationship with the acceptance of illness in women treated for breast cancer
}

\author{
Ocena poziomu poczucia koherencji i jego związek z akceptacją choroby \\ u kobiet leczonych z powodu raka piersi
}

\author{
Marzena Kaźmierczak ${ }^{1, A-F \oplus}$, Grażyna Gebuza ${ }^{2, A, C, E-F \oplus}$, Natalia Czajkowska ${ }^{3, A-C \oplus}$,

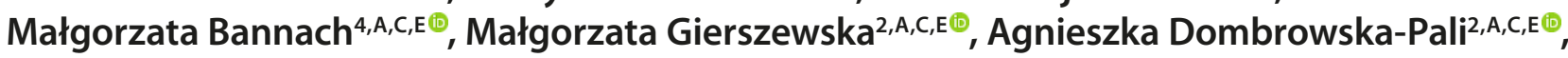 \\ Estera Mieczkowska ${ }^{2, A, C, E \oplus ~}$ \\ 1 Uniwersytet Mikołaja Kopernika w Toruniu Collegium Medicum w Bydgoszczy, Polska \\ ${ }^{2}$ Uniwersytet Mikołaja Kopernika w Toruniu Collegium Medicum w Bydgoszczy Wydział Nauk o Zdrowiu, Polska \\ ${ }^{3}$ Samodzielny Publiczny Wielospecjalistyczny Zakład Opieki Zdrowotnej MSW i A w Bydgoszczy, Polska \\ ${ }^{4}$ Uniwersytet Mikołaja Kopernika w Toruniu, Collegium Medicum w Bydgoszczy, Wydział Nauk o Zdrowiu, Polska \\ A - Research concept and design, B - Collection and/or assembly of data, C - Data analysis and interpretation, \\ $D$ - Writing the article, E - Critical revision of the article, F - Final approval of article
}

\begin{abstract}
Kaźmierczak M, Gebuza G, Czajkowska N, Bannach M, Gierszewska M, Dombrowska-Pali A, Mieczkowska E. Assessment of the level of the sense of coherence and its relationship with the acceptance of illness in women treated for breast cancer. Med Og Nauk Zdr. 2019; 25(4) 266-273. doi: 10.26444/monz/113018
\end{abstract}

\section{Abstract}

Introduction and objective. The sense of coherence plays an important role in the acceptance of illness. The aim of the study was to assess the level of the sense of coherence and its relationship with the acceptance of illness, and to determine whether there are factors which differentiate the sense of coherence and its individual components.

Materials and method. 120 women treated for breast cancer were included in the study. The research project was conducted by means of questionnaires, Life Orientation Questionnaire (SOC-29) and Acceptance of Illness Scale (AIS). The study was approved by the Director of the Professor F. Łukaszczyk Oncology Centre and the Bioethics Committee (KB 320/2017). The research project was conducted from May 2017 - April 2018.

Results. The global level of the sense of coherence in the study sample was at an average level. The average value of the acceptance of illness rate was 26.84 and implied average adaptation to the limitations imposed by an illness. A relationship was found between the level of the sense of coherence and its components, and the degree of the acceptance of illness ( $p<0.00001)$. The methods of treating breast cancer did not determine the level of the sense of coherence and the level of the acceptance of illness ( $p>0.05$ ). The experienced mastectomy did not determine the level of coherence and its components ( $p>0.05)$. A higher level of the acceptance of illness was found in women who had not undergone mastectomy ( $p=0.00007)$.

Conclusions: The study sample presented an average level of the sense of coherence and the acceptance of illness. The sense of coherence significantly correlated with the degree

Address for correspondence: Marzena Kaźmierczak, Nicolaus Copernicus University in Toruń Collegium Medicum in Bydgoszcz, Poland

E-mail: marzena.kazmierczak@cm.umk.pl

Received: 21.08.2019; Accepted: 14.10.2019; first published: 18.11.2019 of the acceptance of illness. Women who had not undergone mastectomy presented a significantly higher level of the acceptance of illness.

\section{Key words}

breast cancer, sense of coherence, Life Orientation Questionnaire (SOC-29), acceptance of illness, Acceptance of IIIness Scale (AIS)

\section{- Streszczenie}

Wprowadzenie. Poczucie koherencji odgrywa istotną rolę w procesie akceptacji choroby.

Cel pracy. Ocena poziomu poczucia koherencji i jego związku z akceptacją choroby oraz ustalenie, czy istnieją czynniki, które różnicują poczucie koherencji i poszczególnych jego komponentów.

Materiał i metody. Badaniem objęto 120 kobiet leczonych z powodu nowotworów piersi. Projekt badawczy zrealizowano za pomocą kwestionariusza ankiety, Kwestionariusza Orientacji Życiowej (SOC-29) i Skali Akceptacji Choroby (AIS). Na przeprowadzenie badania uzyskano zgodę Dyrekcji Centrum Onkologii im. prof. F. Łukaszczyka w Bydgoszczy i Komisji Bioetycznej (KB 320/2017). Projekt badawczy realizowany był od maja 2017 r. do kwietnia 2018 r.

Wyniki. Globalny poziom poczucia koherencji w badanej próbie prezentował się na poziomie przeciętnym. Średnia wartość wskaźnika akceptacji choroby wynosiła 26,84 i świadczyła o przeciętnym przystosowaniu się do ograniczeń narzuconych przez chorobę. Stwierdzono zależność między poziomem poczucia koherencji i jego składowymi a stopniem akceptacji choroby $(p<0,00001)$. Metody leczenia raka piersi nie warunkowały poziomu poczucia koherencji i poziomu akceptacji choroby $(p>0,05)$. Przebycie mastektomii nie warunkowało poziomu koherencji i jego składowych $(p>0,05)$. Wyższy poziom akceptacji choroby dotyczył kobiet, które nie były poddane mastektomii ( $p=0,00007)$. 
Wnioski. Badana próba prezentowała przeciętny poziom poczucia koherencji i akceptacji choroby. Poczucie koherencji istotnie korelowało ze stopniem akceptacji choroby. Kobiety, u których nie wykonano mastektomii, prezentowały istotnie wyższy poziom akceptacji choroby.

\section{INTRODUCTION}

The International Agency for Research Cancer (IARC) has published the latest data on the global incidence of cancer. The global cancer incidence is estimated to have risen to 18.1 million new cases and 9.6 million deaths. In women, the incidence rate of breast cancer significantly exceeds the incidence of other cancers, both in developed and developing countries, and concerns $24.2 \%$, i.e. about 1 in 4 , of all new cancer cases diagnosed in women worldwide. Breast cancer is the leading cause of cancer-related deaths among women (15\%). For comparison, cervical cancer ranks fourth for incidence (6.6\%) [1]. Malignant neoplasms are a growing health, social and an economic problem for Polish society. In 2016, the National Cancer Registry received information on 81,620 first-time reports of malignant neoplasms among women. Most of the ill women were aged from $50-74$. In 2016, the most frequently registered malignant neoplasm in women was breast cancer $(22.8 \%)$ (for comparison, lung cancer $-9.5 \%$, cervical cancer $-3.3 \%)$. Malignant breast cancers are in the second position (after lung cancer) of the percentage of deaths [2].

Cancer among women causes radical changes regarding dysfunctions in the physical, psychological and social spheres. Due to cognitive processes associated with the illness, it is perceived as a source of severe stress, occupying the majority of the patient's consciousness [3].

Negative emotions that accompany cancer cause a decrease in the quality of life, the level of the acceptance of illness, and thus impede the recovery after breast cancer [4]. The acceptance of illness means understanding and agreeing with the changes. It is a long-term process of adapting to cancer, which depends on the personality traits and resistance to stressors. Psychological resources play a vital role in this process, which is associated with the ability to perceive and the willingness to use the offered support and take control of stressful situations [5]. The circumstances in which the diagnosis was made, the lack of support received from family and loved ones, unfavurable financial situation, or the importance of losses (work, position, appearance, independence) have a negative effect on a woman's functioning and, at the same time, the acceptance of a chronic disease [6]. In the face of cancer, a person activates a variety of behaviours focused on coping with a difficult situation. The level of health is a relative and complex concept. Health is understood as a dynamic phenomenon that changes as a result of various life situations that accompany people [7].

A significant factor that contributed to taking an interest in the quality of life of patients with cancer was the emergence of a holistic-functional model in medicine, which, apart from the patient's biological sphere, also takes the mental, social and spiritual sphere into account. The holistic-functional approach is fully visible in the concept of A. Antonovsky's salutogenesis, which assumes that between health and disease there is a continuum of intermediate states which are the result of dynamic processes of demands and resources balancing in stressful life events. In the discussed concept,

\section{Słowa kluczowe}

rak piersi, poczucie koherencji, Kwestionariusz Orientacji Życiowej (SOC-29), akceptacja choroby, Skala Akceptacji Choroby (AIS)

the sense of coherence is the key resource which regulates human relations with the environment, and ultimately determines their health. It is a person's general attitude expressing the degree to which they have a relatively lasting sense of certainty, that life's demands are predictable and explainable (comprehensibility), that they have the resources that will allow them to meet the emerging demands (manageability), and, moreover, that the confrontation with the emerging difficulties is worth their commitment and effort (meaningfulness) [8,9].

\section{OBJECTIVE}

The aim of the study was to assess the level of the sense of coherence and its relationship with the acceptance of illness and determine whether there are factors which differentiate the sense of coherence and its individual components.

\section{MATERIALS AND METHOD}

The study was approved by the Director of the Professor F. Łukaszczyk Oncology Centre and the Bioethics Committee (KB 320/2017). The research project was conducted from May 2017 - April 2018. 120 women hospitalized in the Clinical Ward for Breast Cancer and Reconstructive Surgery and in the Polyclinic at the Oncology Centre were included in the study. The inclusion criterion was diagnosed breast cancer and started treatment. The respondents were informed how to complete the questionnaires and about the possibility of resigning from participation at any stage during the study. The selection of the respondents was deliberate. The survey questionnaires were completed voluntarily and anonymously. Tables 1-3 present the characteristics of the studied sample.

Measures. The research method was a diagnostic survey, and the research tools included: the Life Orientation Questionnaire (SOC-29), Acceptance of Illness Scale (AIS), and a questionnaire of own design. The questionnaire consisted of 30 questions. The first part of the survey contained personal information questions. The subsequent part of the study involved a short obstetric interview (menarche, last menstrual period, fertility, breastfeeding). An oncological interview included: the diagnosis of breast cancer, presence of risk factors for breast cancer, age at breast cancer diagnosis and taking hormone medicines.

The Life Orientation Questionnaire (SOC-29, Sense of Coherence Scale), constructed by A. Antonovsky, is a tool for assessing the level of coherence. It includes 29 questions, each of which is scored on a 7-point Likert scale. The obtained material can be interpreted in the context of the global sense of coherence, as well as in the context of its three components: the sense of comprehensibility (11 questions), the sense of manageability (10 questions) and the sense of 
Table 1. Socio-demographic data of the studied sample

\begin{tabular}{|c|c|c|c|c|}
\hline Socio-demographic data & & Value & $\mathrm{N}$ & $\%$ \\
\hline \multirow{6}{*}{ Age } & $\mathrm{N}$ & - & 120 & - \\
\hline & Mean & 57.68 & - & - \\
\hline & Median & 59 & - & - \\
\hline & SD & 12.43 & - & - \\
\hline & Minimum & 26 & - & - \\
\hline & Maximum & 82 & - & - \\
\hline \multirow{5}{*}{$\begin{array}{l}\text { Age at which breast cancer } \\
\text { was diagnosed }\end{array}$} & Mean & 56.23 & - & - \\
\hline & Median & 58 & - & - \\
\hline & SD & 12.7 & - & - \\
\hline & Minimum & 25 & - & - \\
\hline & Maximum & 81 & - & - \\
\hline \multirow{2}{*}{ Place of residence } & Urban & - & 87 & 72.5 \\
\hline & Rural & - & 33 & 27.5 \\
\hline \multirow{5}{*}{ Marital status } & Single & - & 6 & 5 \\
\hline & Married & - & 75 & 62.5 \\
\hline & Informal relationship & - & 6 & 5 \\
\hline & Divorced & - & 15 & 12.5 \\
\hline & Widow & - & 18 & 15 \\
\hline \multirow{4}{*}{ Education } & Elementary & - & 7 & 5.8 \\
\hline & Vocational & - & 25 & 20.8 \\
\hline & Secondary & - & 51 & 42.5 \\
\hline & Higher & - & 37 & 30.8 \\
\hline \multirow{3}{*}{ Finacial situation } & Very good & - & 4 & 3.3 \\
\hline & Sufficient & - & 104 & 86.7 \\
\hline & $\mathrm{Bad}$ & - & 12 & 10 \\
\hline
\end{tabular}

Source: own study

Table 2. Obstetric data of the studied sample

\begin{tabular}{lcccccc}
\hline & N & Mean & Median & SD & Min. & Max \\
\hline First period (age) & 120 & 13.43 & 13 & 1,90 & 8 & 19 \\
\hline Last period (age) & 91 & 49.86 & 50 & 4.36 & 40 & 57 \\
\hline Number of childbirths & 120 & 1.96 & 2 & 1.12 & 0 & 4 \\
\hline Age at first birth & 107 & 24.64 & 23 & 4.73 & 19 & 41 \\
\hline
\end{tabular}

Source: own study

meaningfulness (8 questions). A high score means a strong sense of life orientation and its components [10].

The Acceptance of Illness Scale (AIS) was created by B. J. Felton et al. and adapted by Z. Juczyński for Polish research. The questionnaire contains eight statements relating to the consequences of bad health condition. Each statement is scored on a five-point scale, where 1 point means "I strongly agree", while 5 points - "I strongly disagree". The sum of points is in the range from $8-40$ and is a general measure of the level of the acceptance of illness. A low score indicates the lack of adaptation to the imposed limitations and a feeling of mental discomfort, whereas a high score means acceptance of the illness and lack of negative emotions [11].
Table 3. The questionnaire data concerning breast cancer prevention

\begin{tabular}{lccc}
\hline Prevention & & $\mathrm{N}$ & $\%$ \\
\hline \multirow{3}{*}{ Breast self-exam } & Once a month & 56 & 46.7 \\
\cline { 2 - 4 } & Every six months & 21 & 17.5 \\
\cline { 2 - 4 } & Once a year & 6 & 5.0 \\
\cline { 2 - 4 } & Never & 37 & 30.8 \\
\hline \multirow{3}{*}{ Detecting changes during self-exam } & Yes & 30 & 25.0 \\
\cline { 2 - 4 } & No & 60 & 50.0 \\
\cline { 2 - 4 } & Not applicable & 30 & 25.0 \\
\hline \multirow{2}{*}{ Mammography } & Yes & 107 & 89.2 \\
\cline { 2 - 4 } & No & 13 & 10.8 \\
\hline \multirow{2}{*}{ Ultrasonography } & Yes & 82 & 68.3 \\
\cline { 2 - 4 } & No & 38 & 31.7 \\
\hline
\end{tabular}

Source: own study

The calculations were made with the $\mathrm{R}$ statistical package, 3.4.2 version. Observation data was collected by means of Microsoft Excel. Non-parametric U Mann-Whitney and Kruskal-Wallis tests were used for data analysis. Due to the non-parametricity of the data distribution, the correlation analysis was performed by means of the Spearman correlation coefficient. Additional analysis of psychometric properties was performed for the AIS scale. Cronbach's alpha coefficient and discriminating power values of items were used to assess the reliability of the scale. Theoretical validity was assessed by means of factor analysis, which was carried out with the method of maximum likelihood with varimax rotation. The presented p-values refer to two-tailed tests. Each hypothesis was tested at the significance level $\mathrm{p}=0.05$ (statistical values for which two-tailed probability was $\mathrm{p}<0.05$ were accepted to be statistically significant).

\section{RESULTS}

The global level of the sense of coherence of the study sample was at an average level (mean 135.72) (Tab. 4). On the basis of the accepted values of the level of coherence in the ranges, it was demonstrated that $40.8 \%$ of the women had a low level of the global sense of coherence, $29.2 \%$ - an average level, while a high level was demonstrated by $30 \%$ of the respondents. The sense of manageability was at an average level of 50.20, the sense of comprehensibility was 44.94 , on average, and the sense of meaningfulness 40.58, on average. Analysis of individual statements of the Life Orientation Questionnaire, divided into the components of the sense of coherence, is presented in Tables 5-7.

Analysis of the level of acceptance of illness based on the basis of the AIS questionnaire was started with psychometric properties - reliability and validity. Due to

Table 4. Descriptive statistics in SOC-29 scale

\begin{tabular}{lcccccc}
\hline Life orientation (SOC) & N & Mean & Median & SD & $\begin{array}{c}\text { Mini- } \\
\text { mum }\end{array}$ & $\begin{array}{c}\text { Maxi- } \\
\text { mum }\end{array}$ \\
\hline Sense of manageability & 120 & 50.20 & 53 & 12.72 & 23 & 70 \\
\hline Sense of comprehensibility & 120 & 44.94 & 48 & 13.05 & 16 & 70 \\
\hline Sense of meaningfulness & 120 & 40.58 & 43 & 11.42 & 13 & 56 \\
\hline Sense of coherence & 120 & 135.72 & 145 & 35.79 & 52 & 191 \\
\hline
\end{tabular}

Source: own study 
Table 5. Descriptive statistics of "the sense of manageability" and individual statements according to SOC-29

\begin{tabular}{|c|c|c|c|c|c|c|}
\hline $\begin{array}{l}\text { Sense of manageability - state- } \\
\text { ment }\end{array}$ & $\mathrm{N}$ & Mean & $\begin{array}{l}\text { Me- } \\
\text { dian }\end{array}$ & SD & $\begin{array}{l}\text { Mini- } \\
\text { mum }\end{array}$ & $\begin{array}{l}\text { Maxi- } \\
\text { mum }\end{array}$ \\
\hline $\begin{array}{l}\text { Doing something in the past with } \\
\text { a group of peers, you had a feeling } \\
\text { that (it definitely wouldnst be done } \\
\text { - it definitely would be done). }\end{array}$ & 120 & 5.31 & 6 & 1.33 & 1 & 7 \\
\hline $\begin{array}{l}\text { Have people you always counted } \\
\text { on let you down? }\end{array}$ & 120 & 5.08 & 5 & 1.42 & 2 & 7 \\
\hline $\begin{array}{l}\text { Do you feel that you are judged } \\
\text { unfairly in your life? }\end{array}$ & 120 & 4.63 & 5 & 1.83 & 1 & 7 \\
\hline $\begin{array}{l}\text { Which statement best describes } \\
\text { your perception of life (there is no } \\
\text { way out of unpleasant life situa- } \\
\text { tions - you can always find a way } \\
\text { out of unpleasant life situations). }\end{array}$ & 120 & 5.03 & 6 & 1.55 & 2 & 7 \\
\hline $\begin{array}{l}\text { When something unpleasant } \\
\text { happened in the past, you tended } \\
\text { (to fret about it and worry - tell } \\
\text { yourself: "it's OK, I have to live with } \\
\text { it", keep doing my job). }\end{array}$ & 120 & 4.23 & 5 & 1.96 & 1 & 7 \\
\hline $\begin{array}{l}\text { What do you think when you do } \\
\text { something that puts you in a good } \\
\text { mood? }\end{array}$ & 120 & 5.36 & 6 & 1.47 & 2 & 7 \\
\hline $\begin{array}{l}\text { Do you think in the future you will } \\
\text { always have people to count on? }\end{array}$ & 120 & 5.49 & 6 & 1.68 & 2 & 7 \\
\hline $\begin{array}{l}\text { Even people with a strong charac- } \\
\text { ter feel lost in certain situations. } \\
\text { How often did you feel this way in } \\
\text { the past? }\end{array}$ & 120 & 5.39 & 6 & 1.52 & 2 & 7 \\
\hline $\begin{array}{l}\text { When you think about obstacles } \\
\text { that you may encounter in your } \\
\text { life, you believe that (you will not } \\
\text { be able to overcome these difficul- } \\
\text { ties - you will always be able to } \\
\text { overcome these difficulties). }\end{array}$ & 120 & 4.73 & 5 & 1.67 & 1 & 7 \\
\hline $\begin{array}{l}\text { How often are you in an emotional } \\
\text { state that you cannot control? }\end{array}$ & 120 & 4.96 & 5 & 1.75 & 1 & 7 \\
\hline Sense of manageability & 120 & 50.20 & 53 & 12.72 & 23 & 70 \\
\hline
\end{tabular}

single measurement in the study, no scale stability analysis was conducted. The reliability was checked on the sample of 120 women by means of the Cronbach alpha and a value of 0.84 was obtained, which is close to the reliability of the original version, for which the Cronbach alpha value is 0.82 . Discriminating power of individual items, estimated as a correlation with the overall result, is in the range between $0.33-0.70$, which confirms the validity of the presence of all questions in the questionnaire. Theoretical validity was tested by factor analysis, assuming theoretical assumptions from the literature about the univariate scale. While extracting one factor, $47.4 \%$ of the variance of the results is explained. Factor loadings of individual items in the questionnaire are in the range from 0.33 to 0.81 (Tab. 8).

Statistical analysis demonstrated that the overall AIS score for the study sample was 26.84 with a range from 11-40, $\mathrm{SD}=7.01$. A low level of the acceptance of illness was found in $19.1 \%$ of the patients, an average level was found in almost half of the women (45.8\%), while a high level was declared by $35 \%$ of the respondents. Analyzing the individual statements of the AIS questionnaire, the lowest average value, and thus the lowest level of the acceptance of illness, were obtained in the statements: 'Health problems make me dependent
Table 6. Descriptive statistics of "the sense of comprehensibility" and individual statements according to SOC-29

\begin{tabular}{lcccccc}
\hline $\begin{array}{l}\text { Sense of comprehensibility - } \\
\text { Statement }\end{array}$ & N & Mean & $\begin{array}{c}\text { Me- } \\
\text { dian }\end{array}$ & SD & $\begin{array}{l}\text { Mini- } \\
\text { mum }\end{array}$ & $\begin{array}{c}\text { Maxi- } \\
\text { mum }\end{array}$ \\
\hline $\begin{array}{l}\text { When you talk to people do you } \\
\text { have a feeling that they do not } \\
\text { understand you? }\end{array}$ & 120 & 4.78 & 5 & 1.74 & 1 & 7 \\
\hline $\begin{array}{l}\text { In everyday life you have contacts } \\
\text { with many people, how do you } \\
\text { evaluate them? }\end{array}$ & 120 & 4.88 & 5 & 1.58 & 1 & 7 \\
$\begin{array}{l}\text { Has it ever happened to you that } \\
\text { a person you know very well be- } \\
\text { haved in a way that surprised you? }\end{array}$ & 120 & 4.62 & 5 & 1.66 & 2 & 7 \\
\hline
\end{tabular}

In recent years your life has been

(full of changes and you did not

$\begin{array}{lllllllll}\text { know what would happen in } & 120 & 4.17 & 4.5 & 1.72 & 1 & 7\end{array}$

a moment - completely in order

and clear).

Do you have the impression that

$\begin{array}{lllllll}\text { you are in an unfamiliar situation } & 120 & 3.40 & 3 & 1.77 & 1 & 6\end{array}$

and you do not know to do?

When you face a difficult problem,

the choice of solution is (always

$\begin{array}{lllllllll}\text { confusing and difficult to make - } & 120 & 3.48 & 3 & 1.32 & 1 & 6\end{array}$

always completely clear).

Your life in the future will be

probably (full of changes and you

$\begin{array}{llllllll}\text { will not know what will happen in } & 120 & 3.66 & 3 & 1.65 & 1 & 6\end{array}$

a moment - completely in order

and clear).

Do you have mixed feelings and $\quad \begin{array}{lllllll} & 120 & 3.77 & 3.5 & 1.73 & 1\end{array}$

\begin{tabular}{llllllll} 
thoughts? & 120 & 3.77 & 3.5 & 1.73 & 1 & 7 \\
\hline Does it happen that you have feel- & 120 & 3.89 & 5 & 1.77 & 1 & 6
\end{tabular}

\begin{tabular}{llllllll} 
ings you would rather not have? & 120 & 3.89 & 5 & 1.77 & 1 & 6 \\
\hline
\end{tabular}

Do you have the impression that

$\begin{array}{llllllll}\text { you do not know what exactly will } & 120 & 3.83 & 5 & 1.79 & 1 & 7\end{array}$

happen?

When something unexpected

happens in your life. you assess

it that (you overestimated or un-

derestimated the meaning of this

event - you saw things in the right

proportions).

\begin{tabular}{lllllll}
\hline Sense of comprehensibility & 120 & 44.94 & 48 & 13.05 & 16 & 70
\end{tabular}

Source: own study

on others more than I want' (mean $=2.71$ ) and 'I will never be as self-sufficient as I would like to be' (mean $=2.93$ ). On the other hand, the highest average value, which means the highest level of adaptation to the illness, was obtained by negating the statement: 'The illness makes me a burden on my family and friends (mean = 3.85) $($ Tab. 9).

While determining the relationship between the parameters of the SOC-29 scale and the AIS scale indicators, a significant correlation was found between the sense of coherence and its components and the acceptance of illness ( $\mathrm{p}<0.00001)$. There was a significant correlation of moderate strength in the positive direction (the strongest relationship existed between the acceptance of illness and the sense of meaningfulness [rho $=0.512]$ ), the weakest was between the acceptance of illness and the sense of comprehensibility $(r h o=0.401)($ Tab. 10).

There was no statistically significant difference ( $p>0.05)$ for the method of breast cancer treatment in the study sample (surgical treatment, chemotherapy, radiotherapy, hormonal therapy) and the level of coherence and its components and 
Table 7. Descriptive statistics of "the sense of meaningfulness" and individual statements according to SOC-29

\begin{tabular}{|c|c|c|c|c|c|c|}
\hline $\begin{array}{l}\text { Sense of meaningfulness - State- } \\
\text { ment }\end{array}$ & $\mathrm{N}$ & Mean & $\begin{array}{l}\text { Me- } \\
\text { dian }\end{array}$ & SD & $\begin{array}{l}\text { Mini- } \\
\text { mum }\end{array}$ & $\begin{array}{l}\text { Maxi- } \\
\text { mum }\end{array}$ \\
\hline $\begin{array}{l}\text { Do you feel that you completely } \\
\text { do not care about the things } \\
\text { around you? }\end{array}$ & 120 & 4.76 & 5 & 1.93 & 1 & 7 \\
\hline $\begin{array}{l}\text { What do you think life is like } \\
\text { (completely monotonous - very } \\
\text { interesting)? }\end{array}$ & 120 & 5.42 & 6 & 1.68 & 1 & 7 \\
\hline $\begin{array}{l}\text { Until now in your life (there have } \\
\text { not been any clear goals or as- } \\
\text { pirations - there have been very } \\
\text { clear goals and aspirations). }\end{array}$ & 120 & 5.11 & 6 & 1.51 & 2 & 7 \\
\hline $\begin{array}{l}\text { Most of what you will do in the } \\
\text { future will be probably (dead bor- } \\
\text { ing - extremely fascinating). }\end{array}$ & 120 & 5.03 & 5 & 1.84 & 1 & 7 \\
\hline $\begin{array}{l}\text { When you think about your life } \\
\text { you very often (ask yourself why } \\
\text { you live at all - you feel how good } \\
\text { it is to live). }\end{array}$ & 120 & 5.24 & 6 & 1.79 & 1 & 7 \\
\hline $\begin{array}{l}\text { Performing everyday activities is } \\
\text { for you a source of (annoyance } \\
\text { and boredom - great pleasure } \\
\text { and contentment). }\end{array}$ & 120 & 5.07 & 5 & 1.62 & 1 & 7 \\
\hline $\begin{array}{l}\text { You predict that your personal life } \\
\text { will be in the future (completely } \\
\text { without meaning or goals - } \\
\text { meaningful with clear goals). }\end{array}$ & 120 & 5.08 & 6 & 1.59 & 1 & 7 \\
\hline $\begin{array}{l}\text { Do you often have a feeling that } \\
\text { what you do does not make } \\
\text { sense? }\end{array}$ & 120 & 4.88 & 5.5 & 1.63 & 1 & 7 \\
\hline Sense of meaningfulness & 120 & 40.58 & 43 & 11.42 & 13 & 56 \\
\hline
\end{tabular}

Source: own study

Table 8. Psychometric properties of AIS scale

\begin{tabular}{ccccc}
\hline AIS - item & Mean & SD & $\begin{array}{c}\text { Correlation of dis- } \\
\text { criminating power }\end{array}$ & $\begin{array}{c}\text { Factor load- } \\
\text { ing }\end{array}$ \\
\hline 1 & 3.20 & 1.22 & 0.54 & 0.66 \\
\hline 2 & 3.29 & 1.33 & 0.59 & 0.71 \\
\hline 3 & 3.75 & 1.32 & 0.70 & 0.81 \\
\hline 4 & 2.71 & 1.20 & 0.33 & 0.33 \\
\hline 5 & 3.85 & 1.23 & 0.67 & 0.63 \\
\hline 6 & 3.75 & 1.26 & 0.58 & 0.66 \\
\hline 7 & 2.93 & 1.26 & 0.64 & 0.69 \\
\hline 8 & 3.36 & 1.42 & 0.50 & 0.46 \\
\hline$\%$ of explained variance & & & & 47.4
\end{tabular}

Source: own study

the level of the acceptance of illness (Tab. 11). Breast removal surgery did not determine the level of coherence and its components ( $p>0.05)$. An average level of the acceptance of illness was higher in the group of women who had not undergone mastectomy $(\mathrm{p}=0.00007)$ (Tab. 12). Breast reconstruction surgery did not differentiate the level of the sense of coherence and the level of the acceptance of illness ( $p>0.05)$. A statistically significant difference was observed only for the sense of meaningfulness $(p=0.0135)$ (Tab. 13).
Table 9. Descriptive statistics of the acceptance of illness and individual statements according to the AIS scale

\begin{tabular}{|c|c|c|c|c|c|c|}
\hline AIS - Statement & $\mathrm{N}$ & Mean & $\begin{array}{l}\text { Me- } \\
\text { dian }\end{array}$ & SD & $\begin{array}{l}\text { Mini- } \\
\text { mum }\end{array}$ & $\begin{array}{l}\text { Maxi- } \\
\text { mum }\end{array}$ \\
\hline $\begin{array}{l}\text { I have difficulty adopting to } \\
\text { the limitations imposed by } \\
\text { the illness. }\end{array}$ & 120 & 3.20 & 3 & 1.22 & 1 & 5 \\
\hline $\begin{array}{l}\text { Because of my health, I am not } \\
\text { able to do what I like best. }\end{array}$ & 120 & 3.29 & 3 & 1.33 & 1 & 5 \\
\hline $\begin{array}{l}\text { The illness makes me feel un- } \\
\text { necessary. }\end{array}$ & 120 & 3.75 & 4 & 1.32 & 1 & 5 \\
\hline $\begin{array}{l}\text { Health problems make me } \\
\text { dependent on others more than } \\
\text { I want. }\end{array}$ & 120 & 2.71 & 3 & 1.20 & 1 & 5 \\
\hline $\begin{array}{l}\text { The illness makes me a burden on } \\
\text { my family and friends. }\end{array}$ & 120 & 3.85 & 4 & 1.23 & 1 & 5 \\
\hline $\begin{array}{l}\text { Because of my condition I do not } \\
\text { feel a full person. }\end{array}$ & 120 & 3.75 & 4 & 1.26 & 1 & 5 \\
\hline $\begin{array}{l}\text { I will never be as self-sufficient as } \\
\text { I would like to be. }\end{array}$ & 120 & 2.93 & 3 & 1.26 & 1 & 5 \\
\hline $\begin{array}{l}\text { I think the people around me } \\
\text { often feel uncomfortable with my } \\
\text { illness. }\end{array}$ & 120 & 3.36 & 4 & 1.42 & 1 & 5 \\
\hline $\begin{array}{l}\text { General indicator of the accept- } \\
\text { ance of illness (AIS). }\end{array}$ & 120 & 26.84 & 27 & 7.01 & 11 & 40 \\
\hline
\end{tabular}

Source: own study

Table 10. Correlation of the level of illness acceptance with the level of the sense of coherence and its components

\begin{tabular}{lcc}
\hline \multirow{2}{*}{ Sense of coherence and its components } & \multicolumn{2}{c}{ AIS } \\
\cline { 2 - 3 } & Correlation coefficient & p-value \\
\hline Sense of coherence & 0.468 & $<0.00001$ \\
\hline Sense of manageability & 0.476 & $<0.00001$ \\
\hline Sense of comprehensibility & 0.401 & $<0.00001$ \\
\hline Sense of meaningfulness & 0.512 & $<0.00001$ \\
\hline
\end{tabular}

Source: own study

Table 11. Correlation of the level of the sense of coherence and its components and the level of illness acceptance with the treatment method

\begin{tabular}{|c|c|c|c|c|c|c|c|c|c|c|}
\hline & \multicolumn{2}{|c|}{$\begin{array}{l}\text { Chemo- } \\
\text { therapy }\end{array}$} & \multicolumn{2}{|c|}{$\begin{array}{l}\text { Surgical } \\
\text { treat- } \\
\text { ment }\end{array}$} & \multicolumn{2}{|c|}{$\begin{array}{l}\text { Hormo- } \\
\text { nal treat- } \\
\text { ment }\end{array}$} & \multicolumn{2}{|c|}{$\begin{array}{l}\text { Radio- } \\
\text { therapy }\end{array}$} & \multirow[t]{2}{*}{$x^{2}$} & \multirow[t]{2}{*}{$\begin{array}{c}\mathrm{p}- \\
\text { value }\end{array}$} \\
\hline & $\mathrm{N}$ & Av. & $\mathrm{N}$ & Av. & $\mathrm{N}$ & Av. & $\mathrm{N}$ & Av. & & \\
\hline $\begin{array}{l}\text { Sense of coher- } \\
\text { ence }\end{array}$ & 52 & 134 & 96 & 137 & 17 & 128 & 30 & 134 & 1.1339 & 0.7689 \\
\hline $\begin{array}{l}\text { Sense of man- } \\
\text { ageability }\end{array}$ & 52 & 49 & 96 & 51 & 17 & 47 & 30 & 50 & 1.2477 & 0.7416 \\
\hline $\begin{array}{l}\text { Sense of } \\
\text { comprehensi- } \\
\text { bility }\end{array}$ & 52 & 45 & 96 & 45 & 17 & 40 & 30 & 42 & 2.9828 & 0.3943 \\
\hline $\begin{array}{l}\text { Sense of mean- } \\
\text { ingfulness }\end{array}$ & 52 & 39 & 96 & 41 & 17 & 41 & 30 & 42 & 1.298 & 0.7296 \\
\hline $\begin{array}{l}\text { Acceptance of } \\
\text { illness }\end{array}$ & 52 & 26 & 96 & 26 & 17 & 27 & 30 & 28 & 1.9149 & 0.5903 \\
\hline
\end{tabular}


Table 12. Comparing the level of the sense of coherence and its components and the level of illness acceptance depending on surgery

\begin{tabular}{lccccccc}
\hline & \multicolumn{2}{c}{ No mastectomy } & \multicolumn{2}{c}{ Mastectomy } & \multirow{2}{*}{ W } & p-value \\
\cline { 2 - 5 } & $\mathrm{N}$ & Mean & $\mathrm{N}$ & Mean & & \\
\hline Sense of coherence & 60 & 141.4 & 60 & 130.1 & 2088.5 & 0.1305 \\
\hline Sense of manageability & 60 & 52.4 & 60 & 48.0 & 2158.5 & 0.06006 \\
\hline Sense of comprehensibility & 60 & 47.0 & 60 & 42.9 & 2039.5 & 0.2092 \\
\hline Sense of meaningfulness & 60 & 42.0 & 60 & 39.2 & 2026 & 0.2361 \\
\hline Acceptance of illness & 60 & 29.2 & 60 & 24.5 & 2556.5 & 0.00007 \\
\hline
\end{tabular}

Source: own study

Table 13. Comparing the level of the sense of coherence and its components and the level of illness acceptance depending on breast reconstruction

\begin{tabular}{lccccccc}
\hline & $\begin{array}{c}\text { No breast re- } \\
\text { construction }\end{array}$ & \multicolumn{2}{c}{$\begin{array}{c}\text { Breast recon- } \\
\text { struction }\end{array}$} & W & p-value \\
\cline { 2 - 6 } & N & Mean & N & Mean & & \\
\hline Sense of coherence & 69 & 130.4 & 20 & 147.6 & 501 & 0.06379 \\
\hline Sense of manageability & 69 & 48.6 & 20 & 53.4 & 557.5 & 0.1941 \\
\hline Sense of comprehensibility & 69 & 43.6 & 20 & 48.8 & 504 & 0.06793 \\
\hline Sense of meaningfulness & 69 & 38.3 & 20 & 45.5 & 438.5 & 0.0135 \\
\hline Acceptance of illness & 69 & 26.3 & 20 & 26.2 & 717 & 0.7937 \\
\hline
\end{tabular}

Source: own study

\section{DISCUSSION}

Negative experiences and severe stress generated by the diagnosis of breast cancer in women cause disorders in the physical and psychological spheres. Cancer diagnosis is associated with a decrease in self-esteem and the quality of life. According to Antonovsky>s concept, the higher the sense of coherence, the better the person 's health.

As a result of the study, it was found that women with breast cancer have an average level of coherence during treatment. The average global level of coherence, obtained by the respondents, was 135.72 points according to the SOC-29 scale; it can therefore be included in the normative values established by the author of the concept of salutogenesis. In analyzing the components of the sense of coherence, it can be concluded that women obtained high results in the manageability component (average 50.20 points), followed by comprehensibility (44.94 points) and meaningfulness (40.58 points). According to Antonovsky>s theory, most important is the sense of meaningfulness, since its lack may render the other components unstable. A person who has a high sense of manageability/control and comprehensibility, and a lower sense of meaningfulness, despite having the appropriate resources, will probably quickly stop understanding signals coming from the world around them. They may also lose control over the resources if they do not have the right motivation [9]. Analyzing the manageability component, the highest average was obtained in the statement: 'Do you think that in the future there will always be people you can count on?' (5.49), and the lowest average in the statement: 'When something unpleasant happened in the past, you tended to fret about it and worry - tell yourself: 'it's OK, I have to live with it', keep doing my job (4.23).

In the component of the sense of comprehensibility, the highest average was obtained in the statement: 'In everyday life you have contacts with many people, how do you evaluate them?' (4.88), and the lowest: 'Do you have the impression that you are in an unfamiliar situation and you do not know what to do?' (3.40). The highest average (5.42) in the meaningfulness component was in the statement: 'What do you think life is like?' (completely monotonous - very interesting), and the lowest related to the statement: 'Do you feel that you completely do not care about the things around you?' (4.76).

Kurowska et al. report that women after mastectomy presented an average level of coherence (SOC mean 137.51 points), where the sense of manageability was 48.33 points, comprehensibility -47.70 points, and meaningfulness -41.48 points [12]. Similar results were obtained by Łepecka-Klusek et al., where an average level of coherence in women with mammary gland pathology was 137 points in the SOC scale. Individual components of the sense of coherence were also on a similar level: manageability - 50 points, comprehensibility - 44.5 points, meaningfulness -42.5 points [13]. Another Kurowska and Czeplickass study indicated a reduced level of coherence in women after mastectomy (mean 127 points) according to SOC [14]. The results of a study by Motyka et al. imply that there is no relationship between the level of the sense of coherence and the quality of life of women after mastectomy. The authors of the study report that, contrary to theoretical assumptions, the sense of coherence is not always associated with an improvement in life satisfaction, which means that the relationships between these two variables are more complicated than it would appear from theoretical assumptions. Furthermore, it was found that the majority of the women with a high sense of coherence relatively quickly decided to see a doctor after noticing worrying changes, while most of the patients with a low sense of coherence postponed this decision and consulted a doctor relatively late. It is likely that people with a higher sense of coherence create a more relevant image of their own illness, which favours desirable health behaviours [15].

Further analysis assessed the level of acceptance of illness in women with breast cancer. Two sources of the acceptance of illness are indicated, the person's personality and the characteristics of the illness [16]; above all, the acceptance of illness is a consent to life changes. In recurrent, incurable diseases, the lack of consent to accept the limitations leads to exhaustion and helplessness [17]. Our own material showed that almost half of the respondents $(45.8 \%)$ presented an average level of acceptance of their health condition. A low level of acceptance was found in $19.1 \%$ of the women, while a high level concerned $35 \%$ of women. The highest average value, which means the highest degree of adjustment to the illness, was obtained by negating the statement: "The illness makes me a burden on my family and friends." The average the acceptance of illness according to the AIS scale was 26.84 points. A higher average (28.13) was obtained by Juczyński in women with breast cancer and uterine cancer [11]. Łuczyk et al. presented results similar to those in the current study in women surgically treated for breast cancer [18]. Bąk-Sosnowska conducted research among women during the first days after mastectomy, and the result reached an average value of 24.56 according to AIS [19]. The results 
obtained by Pawlik et al. show that $46 \%$ of the women coped with adjustment to cancer [20]. Similar results are presented by Nowicki et al., in which $44 \%$ of the women with breast cancer showed a high level of the acceptance of illness during complementary therapy [21]. Lewandowska-Abucewicz et al. report that $42 \%$ of the women after mastectomy achieved a high level of the acceptance of illness, and $37 \%$ of the respondents had no difficulty adapting to the limitations imposed by the illness. The women felt needed (40\%), and half of them (50\%) thought that they were not a burden on family and friends. 32\% of Amazons feel a full person despite their illness [17].

Numerous studies confirm the existence of a correlation between the level of the sense of coherence and the level of the acceptance of illness. In the material presented by Kurowska et al. [12], both the global sense of coherence and all its components were related to the degree of adjustment to the illness. The strongest relationship was demonstrated between the acceptance of illness and the sense of comprehensibility, and then in terms of the sense of manageability. On the other hand, the lowest results were related to the sense of meaningfulness. In the current study, a significant correlation was found between the sense of coherence and its components and the acceptance of illness. The strongest relationship existed between the acceptance of illness and the sense of meaningfulness, the weakest was related to the acceptance of illness and the sense of comprehensibility.

The surgery used to treat breast cancer leads to female body mutilation, diminishes her sense of attractiveness and femininity, or may even lead to body de-sexualization. Women after mastectomy assess themselves as 'incomplete' or 'defective'. Breast reconstruction for these women is a chance to return to a 'normal' life. Breast restoration can have a positive impact on the acceptance of illness, a higher quality of life, and it can be important not only for the woman herself, but also for her environment. The new life situation encourages to define and evaluate the personality features leading, at the same time, to the creation of the ideal self. Discrepancy between self-image and reality may result in a lack of self-acceptance and internal conflicts. This problem seems to be extremely important considering the growing number of women after mastectomy who decide to undergo reconstruction [22]. In the presented study, undergoing breast reconstruction surgery differentiated the component of the sense of meaningfulness in the SOC-29 scale. In the study by Lewandowska-Abucewicz et al. [17], the extent of complementary therapy in women after mastectomy was not related to the level of the acceptance of illness. In the study by Agarwal et al. [23] an increase in life satisfaction in the physical, social and emotional sphere was observed in women after breast reconstruction. The authors report that after breast reconstruction, the women were more extroverted and more socially and sexually active. In the current study, there was no relationship between the way the women were treated for breast cancer (surgery, radiotherapy, hormonal therapy, chemotherapy) and the level of coherence and its components, nor in the level of acceptance of illness. Breast removal surgery did not determine the level of coherence and its components. An average level of the acceptance of illness was higher in the group of women who had undergone breastconserving surgery. Słowik et al. [24] did not show a significant correlation between the type of surgery (one of four variants of surgical treatment) and the overall average quality of life of women after mastectomy. The women who had undergone mastectomy showed better cognitive functioning, reporting at the same time less intense systemic side-effects of treatment than the women after breast-conserving surgery.

It is extremely important to achieve mental balance and return to physical activity for the recovery process of women with breast cancer. The social support received by close family members and friends plays a significant role here. It is also implement early psycho-oncological intervention in the form of supportive therapy and psychoeducation.

\section{CONCLUSIONS}

1. Women with breast cancer presented an average global level of sense of coherence and the acceptance of illness.

2. A significant correlation was found between the sense of coherence and its components and the acceptance of illness. The strongest correlation was between the acceptance of illness and the sense of meaningfulness, the weakest with the sense of comprehensibility.

3. The type of treatment (surgical, chemotherapy, radiotherapy or hormonal) did not determine the level of the sense of coherence and its components and the level of the acceptance of illness.

4. Undergoing breast reconstruction did not differentiate the level of the sense of coherence and the level of the acceptance of illness. A significant difference was observed only for the sense of meaningfulness.

5. The women who had not undergone mastectomy presented a higher level of the acceptance of their health condition.

\section{REFERENCES}

1. International Agency for Research Cancer. World Health Organization 2018. https://www.who.int/cancer/PRGlobocanFinal.pdf [access: 30th September, 2019, at 3:43 p.m.].

2. Wojciechowska U, Czaderny K, Ciuba A, Olasek P, Didkowska J. Malignant neoplasms in Poland in 2016. National Cancer Registry. Ministry of Health 2018. [Nowotwory złośliwe w Polsce w 2016 roku. Krajowy Rejestr Nowotworów. Ministerstwo Zdrowia 2018.] http:// onkologia.org.pl/wp-content/uploads/Nowotwory_2016.pdf [access: 30th September, 2019, at 2:53 p.m.].

3. Pawlik M, Karczmarek-Borowska B. Acceptance of cancer in women after mastectomy [Akceptacja choroby nowotworowej u kobiet po mastektomii.] Prz Med Uniw Rzesz Inst Leków 2013; 2: 203-2011.

4. Lewandowska-Abucewicz T, Kęcka K, Brodowski J. Acceptance of cancer in women after mastectomy in the West Pomeranian Voivodeship - preliminary research. [Akceptacja choroby nowotworowej u kobiet po mastektomii w województwie zachodniopomorskim - badania wstępne.] Fam Med Prim Care Rev 2016; 18(2): 143-148.

5. Łuczyk M, Pietraszek A, Łuczyk R, et al. The intensity and severity of anxiety and depressive disorders in women with breast cancer preparing for surgical treatment. [Występowanie i nasilenie zaburzeń lękowych i depresyjnych u kobiet $\mathrm{z}$ rakiem piersi przygotowywanych do leczenia chirurgicznego.] J Educ Health Sport 2015; 5(5): 52-66.

6. Kosowicz M. Psycho-oncology - selected psychological aspects of functioning with cancer. [Psychoonkologia - wybrane aspekty psychologiczne funkcjonowania w chorobie nowotworowej.] In: Meder J. (ed.) Podstawy onkologii klinicznej. Wydawnictwo CMKP, Warsaw 2011, s. 237-244.

7. Rynkiewicz-Andryśkiewicz M, Andryśkiewicz P, Curyło M, et al. The analysis of the usefulness of assessing the level of the sense of coherence in somatic and mental diseases [Analiza przydatności oceny poziomu poczucia koherencji w chorobach somatycznych i psychicznych.] Prz Med Uniw Rzesz Inst Leków 2014; 4: 365-374. 
8. Motyka M, Dziubak M, Jędrusik P. The sense of coherence and the quality of life of patients treated for breast cancer. [Poczucie koherencji a jakość życia pacjentek leczonych z powodu raka piersi.] Przegl Lek. 2014; 71(5): 270-273

9. Antonovsky A. Unraveling the secret of health. How to deal with stress and not get sick. [Rozwikłanie tajemnicy zdrowia. Jak radzic sobie ze stresem i nie zachorować.] Instytut Psychiatrii i Neurologii, Warsaw 2005.

10. Koniarek J, Dudek B, Makowska Z. Life Orientation Questionnaire. Adaptation of A. Antonovsky's Sense of Coherence Questionnaire (SOC) [Kwestionariusz Orientacji Życiowej. Adaptacja The Sense of Coherence Questionnaire (SOC) A. Antonovsky'ego.] Przegl Psychol 1993; 36(4): 491-502.

11. Juczyński Z. Measurement tools in health promotion and psychology. [Narzędzia pomiaru w promocji i psychologii zdrowia.] Pracownia Testów Psychologicznych Polskiego Towarzystwa Psychologicznego, Warsaw 2009.

12. Kurowska K, Balas E. The sense of coherence and adaptation to life of women after mastectomy. [Poczucie koherencji a przystosowanie się do życia u kobiet po mastektomii.] Curr Gynecol Oncol 2013; 11(3): 191-201.

13. Łepecka-Klusek C, Pilewska-Kozak A, Szyszkowska B, et al. The sense of coherence in women treated for mammary gland pathology. [Poczucie koherencji u kobiet leczonych z powodu patologii gruczołu sutkowego.] Hygeia Public Health 2014; 49(1): 107-112.

14. Kurowska K, Czeplicka J. The sense of coherence (SOC) and the styles of coping with stress as determinants in maintaining optimal health in women after mastectomy. [Poczucie koherencji (SOC) a style radzenia sobie ze stresem jako wyznaczniki w utrzymaniu optymalnego stanu zdrowia u kobiet po mastektomii.] Now Lek. 2009; 78(5-6): 307-311.

15. Motyka M, Dziubak M, Jędrusik P. The sense of coherence and the quality of life of patients treated for breast cancer. [Poczucie koherencji a jakość życia pacjentek leczonych z powodu raka piersi.] Przegl Lek. 2014; 71(5): 270-273

16. Basińska MA, Zalewska-Rydzkowska, D, Wolańska P, et al. Dispositional optimism and illness aceptance in a group of people with Graves disease. [Dyspozycyjny optymizm a akceptacja choroby w grupie osób z chorobą Gravesa-Basedowa.] Endokrynol Pol. 2008; 59: 23-29.

17. Lewandowska-Abucewicz T, Kęcka K, Brodowski J. The acceptance of illness in women after mastectomy in the West Pomeranian Voivodeship - preliminary research. [Akceptacja choroby u kobiet po mastektomii w województwie zachodniopomorskim - badania wstępne.] Fam Med Prim Care Rev 2016; 18(2): 143-148.

18. Łuczyk M, Pietraszek A, Łuczyk R, et al. The acceptance of illness in the group of women surgically treated for breast cancer [Akceptacja choroby w grupie kobiet leczonych chirurgicznie z powodu nowotworu piersi.] J Educ Health Sport 2015; 5(9): 569-576.

19. Bąk-Sosnowska M, Oleszko K, Skrzypulec-Plinta V. Psychological adaptation of mature women on the first days after mastectomy. [Adaptacja psychologiczna dojrzałych kobiet w pierwszych dobach po zabiegu mastektomii.] Prz Menopauz. 2013; 2: 120-124.

20. Pawlik M, Karczmarek-Borowska B. Acceptance of cancer in women after mastectomy. [Akceptacja choroby nowotworowej u kobiet po mastektomii.] Prz Med Uniw Rzesz Inst Leków 2013; 2: 203-2011.

21. Nowicki A, Ostrowska Ż. Acceptance of illness in patients after breast cancer surgery during complementary therapy. [Akceptacja choroby przez chore po operacji raka piersi w trakcie leczenia uzupełniającego.] Pol Merkuriusz Lek. 2008; 24(143): 403-407.

22. Mazurek E. Self-image of women after breast reconstruction. [Obraz siebie kobiet po rekonstrukcji piersi.] Now Lek. 2012; 81(3): 281-287.

23. Agarwal P, Patel AK, Saxena A, et al. Assessment of quality of life after breast reconstructive surgery following mastectomy for carcinoma breast. JSP (International) 2011; 16(2): 50-55.

24. Słowik AJ, Jabłoński MJ, Michałowska-Kaczmarczyk AM, et al. Research on the quality of life of women with breast cancer with particular emphasis on sexual satisfaction and future perspectives and body image depending on the method of surgery. [Badanie jakości życia kobiet $\mathrm{z}$ rakiem piersi, ze szczególnym uwzględnieniem satysfakcji seksualnej i perspektyw na przyszłość oraz obrazu ciała w zależności od zastosowanej metody leczenia operacyjnego.] Psychiatr Pol. 2017; 51(5): 871-888. 